\title{
Pendampingan dan Pengurusan Izin PIRT sebagai Penguatan Produk Olahan Desa Taji, Kecamatan Jabung Kabupaten Malang
}

\author{
Dwi Syanti Wirandhani ${ }^{{ }^{*}}$, Hananingtyas Maharani ${ }^{2}$, Muhammad Izzul Islam ${ }^{3}$, \\ Iqbal Refodikara Mahdiyasa ${ }^{4}$, Sri Winarsih ${ }^{5}$ \\ ${ }^{12345}$ Teknologi Pangan, Fakultas Pertanian Peternakan, Universitas Muhammadiyah \\ Malang \\ E-mail*: dwisyantiwirandhani26@gmail.com
}

\section{Article History:}

Received:Oktober

2021

Revised:November

2021

Accepted:November 2021

Available online:

Desember 2021

\section{Keywords:}

Kue Kering Kopi Taji, Mendol Krispi,

Pendampingan, PIRT,

Sambal Obong.
Abstrak: Desa Taji merupakan desa penghasil kopi dengan jenis kopi Robusta dan Arabica. Desa Taji memiliki badan usaha milik desa yang menjadi binaan mahasiswa Universitas Muhammadiyah Malang pada kegiatan Program Holistik Pembinaan dan Pemberdayaan Desa (PHP2D). Melalui kegiatan PHP2D telah diperoleh hasil pencapaian salah satunya pangan olahan yaitu kue kering kopi. Selain itu terdapat produk lainnya seperti mendol krispi dan sambal obong. Permasalahan yang dialami BUMDes Taji adalah penjualan dan distribusi produk olahan belum meningkat secara signifikan. Solusi dari permasalahan ini adalah adanya izin PIRT sehingga meningkatkan kepercayaan konsumen dan memperluas penjualan. Kegiatan pengabdian masyarakat melalui Program Pengembangan Pemberdayaan Desa (P3D) bertujuan untuk mendampingi BUMDes Taji dalam pengajuan izin PIRT. Metode dalam pengabdian masyarakat ini terdapat empat tahap: persiapan, diskusi bersama, pendaftaran PIRT, monitoring serta evaluasi. Hasil kegiatan pengabdian berupa mitra telah mengajukan izin PIRT dan menunggu tindak lanjut dari dinas kesehatan serta terdapat perubahan terkait produk khas Desa Taji. 


\section{Pendahuluan}

Desa Taji berlokasi di Kecamatan Jabung, Kabupaten Malang terletak di ketinggian 1200 mdpl. Desa Taji merupakan desa penghasil kopi dengan jenis kopi Robusta dan Arabica (Zahro et al., 2020). Tahun 2020, Desa Taji menjadi desa binaan mahasiswa Universitas Muhammadiyah Malang pada kegiatan Program Holistik Pembinaan dan Pemberdayaan Desa (PHP2D). Melalui kegiatan PHP2D telah diperoleh hasil pencapaian salah satunya pengolahan kopi taji menjadi produk olahan yaitu kue kering kopi. Kegiatan tidak berhenti begitu saja, tetapi terus dilakukan melalui Program Pengembangan Pemberdayaan Desa (P3D) sebagai pengembangan lanjutan dari kegiatan Program Holistik Pembinaan dan Pemberdayaan Desa (PHP2D). Kue kering kopi sebagai produk khas Desa Taji melalui beberapa tahapan yaitu pencampuran bahan, pembuatan adonan, pencetakan, pemanggangan, hingga pengemasan.

Kue kering Kopi Taji telah dikemas dengan kemasan dan label yang baik serta masyarakat desa dibina untuk melakukan pemasaran secara online maupun offline. Hasil kemutakhiran data yang diperoleh dari desa menunjukan bahwa kue kering kopi belum terjadi peningkatan penjualan yang signifikan di setiap bulannya. Hingga saat ini, rata-rata setiap bulannya terjual hanya berkisar $4 \mathrm{~kg}$ kue kering kopi yang menunjukan penerimaan masyarakat terhadap produk olahan belum banyak serta belum meluasnya pangsa pasar. Begitu pula dengan beberapa produk olahan Desa Taji lainnya seperti mendol krispi dan sambal obong. Mendol merupakan salah satu olahan dari tempe yang memiliki aroma cenderung kurang sedap sehingga diolah kembali ( Fitriah et al., 2017). Mendol krispi ini memiliki cita rasa gurih dan tapak kuning kecoklatan yang berasal dari bumbu yang ditambahkan.

Sambal obong merupakan olahan berbahan dasar cabai yang ditambahkan bahan seperti daun bawang, terasi, garam kemudian dimasak langsung di atas cobek. Sambal ini menjadi andalan wisatawan yang berkunjung dan menjadi sajian nikmat disantap dengan nasi hangat. Proses produksi dilakukan di rumah dan menjadi satu dengan tempat tinggal. Produksi olahan khas taji masih tergolong sederhana seperti penggunaan alat yang sederhana serta tahapan pengolahan yang dilakukan secara batch. Produk tersebut hanya dapat dijual di kedai desa dan sekitarnya, belum bisa diedarkan ke mini market, toko oleh-oleh maupun luar desa. Hal ini disebabkan oleh 
Badan Usaha milik Desa (BUMDes) yang belum memiliki legalitas layak edar seperti PIRT (Pangan Industri Rumah Tangga). Sehingga perlu tindak lanjut program untuk bisa menguatkan penerimaan produk ke masyarakat sehingga akan semakin luas jangkauan pemasarannya, salah satunya dengan pengurusan PIRT. Pangan Industri Rumah Tangga (PIRT) merupakan suatu perusahaan yang mempunyai lokasi produksi menetap dengan alat pengolahan yang sederhana (BPOM, 2018). Fitriah (2017) menyatakan bahwa Peraturan Pemerintah Pasal 43 No.28 Tahun 2004 tentang keamanan, mutu dan gizi pangan industri rumah tangga yang memiliki usaha di bidang pangan mengharuskan mempunyai Sertifikat Produksi Pangan Industri Rumah Tangga (SPP-IRT). Sertifikat Produksi Pangan Industri Rumah Tangga (SPP-IRT) merupakan sebuah dokumen resmi tertulis yang diberikan dari pemerintah kota dan sangat dibutuhkan oleh UKM di Desa Taji agar dapat menjual produk dengan layak dan legal. Melalui pendamping oleh tim P3D menjadi solusi yang tepat untuk peningkatan serta pengembangan dari BUMDes Taji dari aspek sumber daya manusia maupun manajemen dan tata kelola usaha. Tujuan dilakukannya pengabdian masyarakat melalui pendampingan ini adalah membantu masyarakat Desa Taji khususnya ibu PKK dalam perizinan produk PIRT serta melengkapi berkas administrasi untuk meningkatkan penerimaan produk serta menjamin kepercayaan konsumen di pasaran. Luaran dari kegiatan ini adalah menghasilkan produk yang mendapatkan PIRT dari Dinas Kesehatan. Kondisi BUMDes Taji pasca program PHP2D atau sebelum kegiatan P3D disajikan pada Tabel 1.

Tabel 1. Kondisi BUMDes Taji sebelum kegiatan P3D

\begin{tabular}{lll}
\hline \multicolumn{1}{c}{ No } & \multicolumn{1}{c}{ Kelengkapan } & \multicolumn{1}{c}{ Keterangan } \\
\hline 1. & Nama Dagang & Ada \\
\hline 2. & Berat Bersih & Belum Ada \\
\hline 3. & Informasi Komposisi & Ada \\
\hline 4. & Informasi Kode Kadaluarsa & Belum Ada \\
\hline 5. & SPP-IRT & Belum Ada \\
\hline 6. & Produksi & Bergantung pesanan \\
\hline 7. & Pemasaran & Terbatas di sekitar Desa Taji \\
\hline
\end{tabular}

ISSN: 1693-8046 (Print), ISSN: 2615-4544 (Online) 
Berdasarkan permasalahan yang dihadapi oleh BUMDes Taji dan melihat urgensi dari kegiatan Program Pengembangan Pemberdayaan Desa (P3D), maka solusi yang diberikan tercantum pada Tabel 2 berikut.

Tabel 2. Permasalahan dari BUMDes Taji

\begin{tabular}{llr}
\hline Permasalahan & Solusi \\
\hline Belum dimilikinya sertifikat Pangan & Mengadakan diskusi terkait \\
Industri Pangan Rumah Tangga dan & pentingnya legalitas izin PIRT bagi \\
nomor PIRT untuk produk usaha kue & produsen BUMDes Taji serta \\
kering kopi, mendol krispi dan & penyuluhan terkait persyaratan dan \\
sambal obong BUMDes Taji & cara mendapatkan izin tersebut. \\
& $\begin{array}{l}\text { Pendampingan pengurusan dan } \\
\text { pengajuan dokumen PIRT ke Dinas } \\
\end{array}$ \\
& Kesehatan Kabupaten Malang. \\
\hline
\end{tabular}

\section{Metode}

Kegiatan pengabdian masyarakat kali ini yaitu blended, kegiatan koordinasi tim P3D dilaksanakan secara daring, sedangkan kegiatan koordinasi bersama Ibu PKK Desa Taji maupun pengurusan administrasi dilakukan secara luring dengan menggunakan protokol kesehatan. Metode yang dilakukan dengan cara memberikan sosialisasi atau diskusi serta pendampingan pengurusan izin legalitas PIRT (Pangan Industri Rumah Tangga) yang dilaksanakan dari bulan Agustus-Desember 2021 kepada BUMDes Taji.

Tahapan awal meliputi beberapa kegiatan yaitu dari mulai persiapan koordinasi tim dan penyusunan action plan, Selanjutnya melakukan persiapan pokok bahasan diskusi kepada mitra BUMDes atau ibu PKK Desa Taji. Tahapan kedua yaitu diskusi kepada ketua BUMDes Taji. Adapun pembahasan yang disampaikan yaitu (1) Pentingnya izin legalitas produk bagi UMKM. (2) Cara produksi pangan olahan yang baik dari kualitas produk, kebersihan, hingga keamanan produk. (3) Persyaratan berkas yang harus dilengkapi di dalam formulir tersebut untuk surat izin legalitas PIRT (Pangan Industri Rumah Tangga) serta melakukan pemeriksaan sarana seperti layout tempat produksi, kebersihan produksi. Tahapan ketiga yaitu tahapan pengumpulan berkas syarat pengajuan izin PIRT, pendampingan pengisian formulir pendaftaran untuk pengajuan izin PIRT ke pihak Dinas Kesehatan, 
Kabupaten Malang. Kemudian akan ditindaklanjuti oleh Dinas Kesehatan berupa jadwal penyuluhan dari Dinas Kesehatan. Kemudian tahapan terakhir yaitu monitoring dan evaluasi. Setelah mendapatkan pengetahuan beberapa informasi tentang PIRT oleh Dinkes Kabupaten Malang, Jawa Timur dan menunggu hingga hampir 2 bulan untuk mendapatkan surat izin legalitas PIRT (Pangan Industri Rumah Tangga) dan nomor PIRT. Selanjutnya yaitu pengabdian masyarakat ini membantu untuk menerapkan No. PIRT pada label setiap produk olahan BUMDes Taji. Setelah nantinya mendapatkan surat izin legalitas atau nomor PIRT ini produk olahan BUMDes Taji telah layak untuk diedarkan di dalam maupun luar daerah.

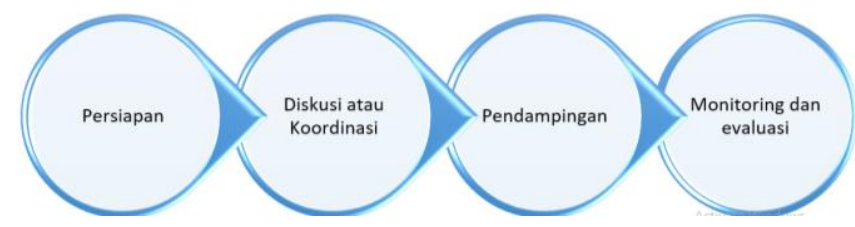

Gambar 1. Metode Pelaksanaa

\section{Hasil}

Pelaksanaan pengabdian masyarakat dengan program P3D kegiatan pendampingan BUMDes Taji merupakan rangkaian kegiatan penguat produk olahan khas Desa Taji salah satunya dengan pendampingan pengurusan izin PIRT. Adapun rincian kegiatan meliputi persiapan, pelaksanaan, dan monitoring serta hasilnya antara lain:

\section{1) Tahapan persiapan}

Pada tahap ini dilaksanakan koordinasi tim dan penyusunan action plan, job desk antar anggota, hingga persiapan untuk diskusi kepada ketua BUMDes terkait kegiatan pendampingan.

\section{2) Tahap Diskusi}

Tahapan kedua adalah diskusi bersama ketua BUMDes yang disajikan pada Gambar 2. 


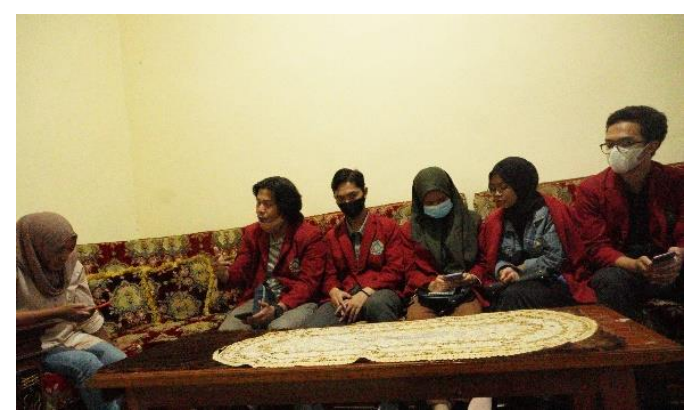

Gambar 2. Diskusi bersama Ibu Zeni (Ketua BUMDes Taji)

Adapun pokok bahasan yang disampaikan meliputi: (a) Pentingnya izin legalitas produk. Izin legalitas berupa izin PIRT memberi keuntungan bagi produk, pelaku usaha atau UMKM, dan konsumen yakni terjaminnya produk yang dihasilkan berkualitas baik dan aman. (b) Cara produksi pangan olahan yang baik (CPPOB). Hal ini disampaikan untuk meminimalisir pangan yang tidak aman dikonsumsi. Beberapa aspek CРPOB yang disampaikan seperti lokasi dan lingkungan produksi, sanitasi dan higiene, serta penyimpanan. Penyampaian mengenai CPPOB - sekaligus melakukan pemeriksaan kondisi ruang produksi oleh tim P3D yang mengacu pada Peraturan Kepala BPOM Nomor HK.03.1.23.04.12.2207 mengenai Tata Cara Pemeriksaan Sarana Produksi Pangan Industri Rumah Tangga (BPOM RI, 2012). Berdasarkan kondisi ruang produksi BUMDes Taji, lokasi di luar ruang masih terawat, namun terdapat seperti kucing dan ayam yang berkeliaran di halaman samping lokasi produksi. Tempat produksi memiliki sirkulasi udara yang cukup baik. Layout pada ruang produksi olahan BUMDes Taji belum disusun secara sistematis dan belum mengikuti alur proses produksi sebelumnya. Kondisi tempat produksi belum memenuhi CPPOB sepenuhnya yang mengacu pada peraturan BPOM RI (2011), lantai tempat pengolahan produk belum menggunakan jenis lantai kedap air, diantara ruang pencucian dan ruang penyimpanan tidak ada sekat pemisah. Pemeliharaan alat produksi dilakukan pembersihan menggunakan air dan sabun pencucian biasa. Layout ruang produksi disajikan pada Gambar 3 berikut. 
Dharma Raflesia

Jurnal Ilmiah Pengembangan dan Penerapan IPTEKS

Vol. 19, No. 02, Desember, 2021, pp. $234-246$

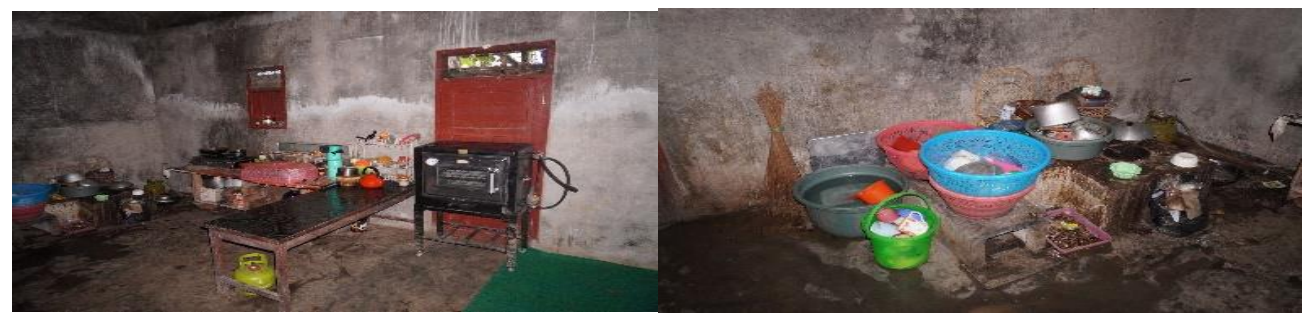

Gambar 3. Layout Ruang Produksi (Kiri); Tempat Pencucian setelah Produksi

(Kanan)

(c) Persyaratan berkas yang harus dilengkapi dalam formulir pendaftaran izin PIRT. Adapun persyaratan berkas yang wajib dipenuhi yaitu: melakukan pengisian formulir pendaftaran; fotokopi sertifikat Penyuluhan Keamanan Pangan (PKP); fotokopi KTP pemilik usaha atau penanggung jawab; fotokopi hasil pemeriksaan air dan pembayaran rekening PDAM; rancangan denah petunjuk lokasi, layout produksi, rancangan label pangan, daftar produk yang diajukan dan nomor induk izin berusaha (Arifudin, 2020). Label produk yang telah diajukan dan masih menunggu izin PIRT , dapat dilihat pada Gambar 4 berikut.

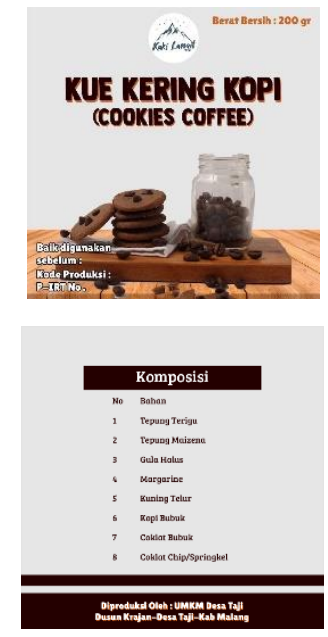

(a)
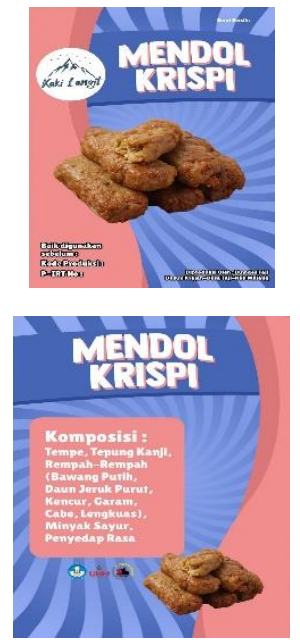

(b)
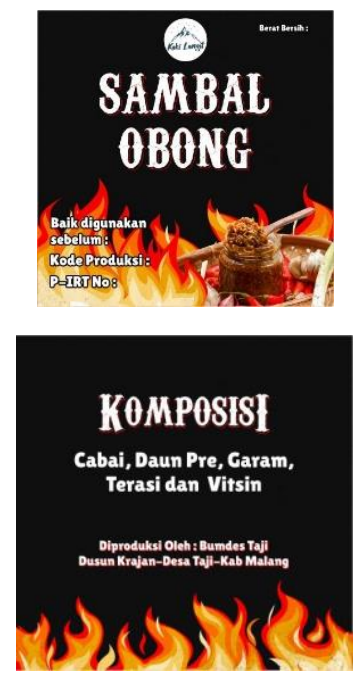

(c) 
Gambar 4. Label produk yang diajukan izin PIRT: (a) Kue Kering Kopi; (b) Mendol Krispi; (c) Sambal Obong

\section{3) Tahap Pendampingan}

Tahapan selanjutnya adalah pendampingan dalam mempersiapkan administrasi yang dibutuhkan dalam pengajuan izin PIRT ke Dinas Kesehatan Kabupaten Malang. Berdasarkan survei yang telah dilakukan masih ditemukan beberapa persyaratan yang kurang lengkap seperti stempel perusahaan, peta lokasi serta denah bangunan. Ketentuan yang ditetapkan untuk stempel berdasarkan Keputusan Ka BPOM RI No. HK.00.05.5.1640 mengenai pedoman tata cara penyelenggaraan sertifikasi produksi pangan industri rumah tangga tersebut harus memuat merek, nama perusahaan dan alamat BUMDes Taji. Oleh sebab itu, tim P3D UMM melakukan pendampingan terhadap pembuatan stempel sesuai ketentuan serta pembuatan peta lokasi dan denah lokasi. Seluruh berkas yang telah dipersiapkan kemudian diserahkan ke Dinas Kesehatan Kabupaten Malang.

Selanjutnya pelaku usaha atau UMKM yang dalam hal ini diwakili oleh ketua BUMDes Taji diwajibkan untuk mengikuti kegiatan penyuluhan keamanan pangan yang dilaksanakan oleh Dinas Kesehatan Kabupaten Malang sesuai jadwal yang ditentukan. Adanya pemberlakuan pembatasan kegiatan masyarakat (PPKM) sehingga penyuluhan diadakan secara online.

\section{4) Monitoring dan Evaluasi}

Setelah dilakukannya penyuluhan mengenai PIRT dan kelayakan produksi oleh Dinkes Kabupaten Malang, BUMDes Taji membutuhkan waktu tunggu relatif lama berkisar 2 bulan untuk mendapatkan surat izin legalitas PIRT (Pangan Industri Rumah Tangga) dan nomor PIRT. Serangkaian kegiatan pengabdian oleh tim P3D telah dilakukan sesuai rencana kegiatan. Tahap berikutnya adalah evaluasi kegiatan yang telah dilaksanakan untuk melakukan perbaikan terhadap kendala yang dialami saat kegiatan berlangsung. Adapun beberapa kendala sehingga perlunya dilakukan monitoring dan evaluasi sebagai berikut : 1 . Sulitnya penyesuaian waktu antara tim P3D dan ketua Ibu PKK melakukan sosialisasi kepada Ibu PKK Desa Taji; 2. Kurang pemahaman atau pengetahuan tentang pentingnya izin legalitas pada suatu produk untuk dipasarkan secara meluas; 3. Persyaratan administrasi yang kurang lengkap 
sehingga dilakukan revisi ulang terkait pengumpulan berkas pengajuan izin PIRT serta proses pembuatan sertifikat PIRT membutuhkan waktu sangat cukup lama karena pemohon di dinas Kabupaten Malang tidak sedikit.

Hasil kegiatan diukur melalui keberhasilan program pengabdian terhadap BUMDes Taji yang disajikan pada Tabel 3 berikut.

Tabel 3. Kondisi BUMDes Taji setelah Kegiatan P3D

\begin{tabular}{|c|c|c|}
\hline Kelengkapan & $\begin{array}{c}\text { Sebelum } \\
\text { Pendampingan }\end{array}$ & Setelah Pendampingan \\
\hline Nama dagang & Ada & $\begin{array}{l}\text { Ada (Kue Kering Kopi, } \\
\text { Mendol Crispy, Sambal } \\
\text { Obong) }\end{array}$ \\
\hline Informasi Berat Bersih & Belum Ada & Ada \\
\hline Informasi Komposisi & Ada & Ada \\
\hline $\begin{array}{ll}\text { Informasi } & \text { Kode } \\
\text { Kadaluarsa } & \end{array}$ & Belum Ada & Ada \\
\hline SPP-IRT & Belum ada & Ada \\
\hline Produksi & Bergantung pesanan & Produksi setiap minggu \\
\hline Pemasaran & $\begin{array}{l}\text { Terbatas di sekitar } \\
\text { Desa Taji }\end{array}$ & $\begin{array}{l}\text { Melakukan penjualan di } \\
\text { sekitar secara langsung } \\
\text { maupun } \\
\text { commelalui e- }\end{array}$ \\
\hline
\end{tabular}

\section{Diskusi}

Berdasarkan hasil pengabdian diperoleh kesadaran warga khususnya BUMDes Taji dalam pentingnya melakukan perizinan produk seperti PIRT untuk meningkatkan kepercayaan konsumen. Selain itu dapat menguatkan kepercayaan pembeli sehingga distribusi pasar lebih luas yang akan berdampak pada meningkatnya omzet penjualan (Nasution, 2020). Pada kegiatan diskusi melalui BUMDes Taji, beberapa aspek CPPOB yang disampaikan seperti lokasi dan lingkungan produksi, sanitasi dan higiene, serta penyimpanan. Hal ini sebagai upaya pendukung penguatan produk, tidak hanya dalam legalitas tetapi juga dalam aspek produksi dan higienitas. Upaya ini perlu dilakukan walaupun tidak dilaksanakan evaluasi pada 14 aspek keseluruhan CPPB-IRT, setidaknya dilakukan pembenahan secara bertahap terutama terhadap kondisi bangunan, peralatan kebersihan dan 
pengawasan karyawan.

Pada kegiatan pengumpulan berkas administrasi pendaftaran PIRT diperoleh pengetahuan mengenai kelengkapan berkas yang harus dipenuhi. Tidak hanya melakukan pendampingan dalam kelengkapan administrasi, kegiatan lainnya seperti melakukan pembaruan label dan kemasan. Sama halnya pada pengabdian yang dilakukan oleh Hutami (2019) bahwa perbaikan label dan kemasan dengan tujuan untuk menambah estetika produk dan memperpanjang masa simpan yang mengacu pada peraturan pemerintah No. 69 Tahun 1999.

Permohonan SPP-IRT telah diterima oleh Dinas Kesehatan Malang untuk dilakukan pemeriksaan formulir pendaftaran serta label yang telah sesuai aturan. Desain label disajikan pada Gambar 4, telah dilaporkan seluruh berkas sudah memenuhi persyaratan. Tahap berikutnya adalah penyuluhan keamanan pangan. Adapun materi penyuluhan yang diberikan terdiri dari materi utama dan materi tambahan. Materi utama yang disajikan adalah sanitasi dan higienitas, jenis bahaya, kontaminasi silang dan cara mengatasinya, cara produksi pangan yang baik industri rumah tangga (CPBB-IRT), dan lainnnya. Materi tambahan mencakup pengemasan dan penyimpanan serta pengembangan usaha (Koswara \& Diniari, 2015). Tahap selanjutnya adalah Dinas Kesehatan melakukan pemeriksaan pada tempat produksi. Jika ditemukan ketidaksesuaian dengan pedoman pemeriksaan sarana produksi IRTP maka diadakan perbaikan (Purba et al., 2014). Penyuluhan yang dilakukan disertai dengan post test, dimana peserta yang mengikuti evaluasi atau post test harus mendapatkan nilai minimal Cukup (60) untuk memperoleh sertifikat penyuluhan keamanan pangan (SPKP). Sertifikat ini diberikan pada peserta yang sudah berpartisipasi dalam kegiatan dan tidak memiliki batasan berlaku pada sertifikat (Yulianti \& Mustarichie, 2018). Sertifikat produksi pangan industri rumah tangga (SPP-IRT) diberikan ketika hasil evaluasi tempat produksi hingga sarana sudah memenuhi syarat setempat dengan nilai minimal Cukup (Purba et al., 2014). Penyuluhan tersebut dimaksudkan untuk dapat meningkatkan kesadaran pelaku usaha terkait pengolahan produk pangan yang baik dan sesuai dengan ketentuan keamanan pangan dari pemerintah, guna memberikan hasil olahan produk yang baik bagi konsumen dari segi kualitas produk maupun keamanannya.

Setelah dilakukannya pendampingan, tim melakukan monitoring pada 
BUMDes Taji dan dalam memproduksi produk olahan khas Desa Taji menjadi lebih baik,serta proses produksi lebih higienis, yang disajikan pada Gambar 5.

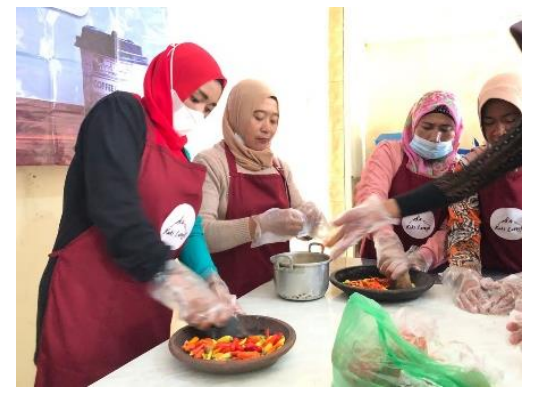

Gambar 5. Produksi sambal obong

Secara keseluruhan kegiatan pendampingan pengajuan PIRT pada BUMDes Taji yang telah dilakukan menunjukan partisipasi aktif dalam proses pengajuan hingga perbaikan BUMDes. Hal ini terlihat ketika ketua BUMDes Taji selalu menyampaikan kendala atau pertanyaan dengan aktif saat proses pengumpulan berkas, para anggota ikut turut serta dalam pembenahan kondisi produksi serta memiliki kesadaran tentang higienitas saat produksi. Hal ini sejalan dengan Saugi \& Sumarno (2015) menyatakan bahwa, indikator keberhasilan ditunjukkan dengan meningkatnya pengetahuan, keterampilan dalam seluruh aspek. Secara akumulatif, hal ini berdampak pada peningkatan pendapatan pada BUMDes Taji.

\section{Kesimpulan}

Hasil pelaksanaan Program Pengembangan Pemberdayaan Desa (P3D) melalui pendampingan dan mengurus izin PIRT bagi BUMDes Taji telah terlaksana dengan baik. Proses pendampingan dilakukan hingga tahap menunggu penerbitan nomor PIRT, selain itu kegiatan pengabdian telah memberikan perubahan terhadap mitra seperti kelayakan tempat dan proses produksi, pengembangan kemasan, peningkatan frekuensi produksi serta perluasan pemasaran.

\section{Pengakuan}

Terima kasih kami sampaikan kepada Kementerian Pendidikan dan Kebudayaan yang telah mendanai pengabdian ini melalui kegiatan Program 
Pengembangan Pemberdayaan Desa (P3D).

\section{Daftar Referensi}

Arifudin, O. (2020). Pembuatan Kemasan Dan Perluasan Pemasaran Minuman Sari Buah Nanas Khas Kabupaten Subang Jawa Barat. Jurnal Pengabdian Kepada Masyarakat, 3(2), 20-28. https://doi.org/10.36257/apts.v3i2.2053

Badan Pengawas Obat dan Makanan (BPOM). (2018). Pedoman Pemberian Sertifikasi Produksi Pangan Industri Rumah Tangga. Badan Pengawas Obat Dan Makanan, 1-16.

BPOM RI. (2011). Peraturan Kepala Badan Pengawas Obat dan Makanan Republik Indonesia Nomor HK.03.1.23.12.11.10569 Tentang Pedoman Cara Ritel Pangan yang Baik. Bpom Ri.

BPOM RI. (2012). Badan Pengawas Obat dan Makanan Republik Indonesia No.HK.03.1.23.04.12.2206. 4.

Fitriah, A. H., Kristianto, Y., \& Pudjirahaju, A. (2017). Kreativitas Pengembangan Formula Tempe Generasi Dua Di Kota Malang. Jurnal Informasi Kesehatan Indonesia, 3(2), 96-103.

Fitriah, M., \& Kusumadinata, A. A. (2017). Informasi Label Kemasan "Mochibo." Jurnal Sosial Humaniora, 8(2), 112. https://doi.org/10.30997/jsh.v8i2.885

Hutami, R., Amalia, L., Aminah, S., \& Agusta, E. N. (2019). Pendampingan Pendaftaran Sertifikasi Pangan Industri Rumah Tangga (Pirt) Ukm Pangan Berbasis Talas Dan Nanas Bogor Di Kota Bogor. Jurnal Qardhul Hasan; Media Pengabdian Kepada Masyarakat, 5(2), 57-63.

Koswara, S., \& Diniari, A. (2015). Peningkatan Mutu dan Cara Produksi pada Industri Minuman Jahe Merah Instan di Desa Benteng, Ciampea , Bogor ( Quality Improvement and Manufacturing Practices for Instant Red Ginger Beverage Industry in Benteng Village , Ciampea , Bogor ). Jurnal Ilmiah Pengabdian Kepada Masyarakat, 1(November), 149-161.

Nasution, S. H. (2020). Perlindungan Hukum Terhadap Konsumen Terkait Produk

Frozen Food Tanpa Izin Edar Yang Dijual Secara Online. Jurnal Legal Reasoning, 3(1), 65-79.

Purba, D. F., Nuraida, L., \& Koswara, S. (2014). Efektivitas Program Peningkatan Mutu Dan Keamanan Pangan Industri Rumah Tangga Pangan (Irtp) Di $\begin{array}{lllll}\text { Kabupaten Cianjur. Jurnal Standardisasi, } & 16(2),\end{array}$ https://doi.org/10.31153/js.v16i2.172

Saugi, W., \& Sumarno, S. (2015). Pemberdayaan Perempuan melalui Pelatihan Pengolahan Bahan Pangan Lokal. Jurnal Pendidikan Dan Pemberdayaan Masyarakat, 2(2), 226. https://doi.org/10.21831/jppm.v2i2.6361 
Yulianti, M. D., \& Mustarichie, R. (2018). Tata Cara Registrasi Untuk Pangan Olahan Industri Rumah Tangga (Pirt) Dan Makanan Dalam Negeri (Md) Dalam Rangka Peningkatan Produk Yang Aman Dan Bermutu Di Bandung Jawa Barat. Farmaka, 15(3), 57-64.

Zahro, I. L., Latifa, D. D., Alam, I. N., \& Rosania, S. P. (2020). Pelatihan Pembuatan Cookies Kopi untuk Meningkatkan Potensi Olahan Kopi dan Mengembangkan Keterampilan Anggota PKK Desa Taji , Kecamatan Jabung ,. Jurnal Akses Pengabdian Indonesia, 5(2), 76-81. 